\title{
The Effects of Petroselinum Crispum on Estrogen Receptor-positive Benign and Malignant Mammary Cells (MCF12A/MCF7)
}

\author{
LENNARD SCHRÖDER ${ }^{1}$, JULIAN KOCH ${ }^{1}$, SVEN MAHNER $^{1}$, BERND P. KOST ${ }^{1}$, SIMONE HOFMANN ${ }^{1}$, \\ UDO JESCHKE $^{1}$, JENS HAUMANN ${ }^{2}$, JULIAN SCHMEDT ${ }^{2}$ and DAGMAR ULRIKE RICHTER ${ }^{2}$ \\ ${ }^{1}$ LMU Munich, Department of Obstetrics and Gynecology, Munich, Germany; \\ ${ }^{2}$ University of Rostock, Department of Obstetrics and Gynecology, Klinikum Sued, Rostock, Germany
}

\begin{abstract}
Background: Phytoestrogens have controversial effects on hormone-dependent tumors. Herein we investigated the effects of parsley root extract (PCE) on DNA synthesis performance, metabolic activity and cytotoxicity in malignant and benign breast cells. Materials and Methods: The PCE was prepared and analyzed by mass spectrometry. MCF7 and MCF12A cells were incubated with various concentrations of PCE and analyzed for DNA synthesis performance, metabolic activity and cytotoxicity by BrdU proliferation, MTT and LDH assays, respectively. Results: PCE was found to contain a substantial ratio of lignans. At a concentration range of $0.01 \mu \mathrm{g} / \mathrm{ml}-100 \mu \mathrm{g} / \mathrm{ml}$ the $\mathrm{LDH}$ assay analysis showed no significant cytotoxicity of PCE in both cell lines. However, at $500 \mu \mathrm{g} / \mathrm{ml}$ PCE's cytotoxicity was well over $70 \%$ of total cell population in both cell lines. According to the BrdU proliferation assay analysis, PCE demonstrated significant DNA synthesis inhibition of up to $80 \%$ at concentrations of $10,50,100$ and $500 \mu \mathrm{g} / \mathrm{ml}$ in both cell lines. Based on the MTT assay analysis, only at a concentration of $500 \mu \mathrm{g} / \mathrm{ml}, \mathrm{PCE}$ demonstrated a statistically significant inhibition of cellular metabolic activity of $63 \%$ in MCF7 and $75 \%$ in MCF12A of their respective normal capacity. Conclusion: PCE showed antiproliferative effects in MCF7 and MCF12A cells. Further investigation is required to determine whether this effect can be solely attributed to its phytoestrogens.
\end{abstract}

Correspondence to: Professor Dr. Udo Jeschke, Department of Gynecology and Obstetrics, Campus Innenstadt, Ludwig Maximilian University Munich, Maistr. 11, D-80337 Munich, Germany. Tel: +49 89440054240, Fax: +49 89440054169, e-mail: udo.jeschke@med.uni-muenchen.de

Key Words: Petroselinum crispum, estrogen receptor, breast cancer, MCF7, MCF12A.
Breast cancer, alongside bronchial and colorectal cancer, is one of three most commonly diagnosed cancers in women. It accounts for almost one third of all cancers diagnosed in women (1). The most prevalent type of breast cancer $(65 \%)$ is estrogen (ER) and progesterone (PR) receptor-positive (2). For all patients diagnosed with hormone receptor positive breast cancer, endocrine therapy is recommended either with tamoxifen, a selective estrogen receptor antagonist (SERM) or with an aromatase inhibitor, depending on the menopausal status and comorbidities. Although endocrine therapy has led to a considerable decline in breast cancer mortality, endocrine resistance often causes disease progression, leading to metastasis with a poor 5-year relative survival outcome (23\%) (3).

Phytoestrogens are a group of plant-derived polyphenolic compounds, their chemical structures resemble that of estrogen (4). Due to their molecular structures these compounds can bind and interact with human ER and PR resulting in both estrogen and anti-estrogen effects $(5,6)$. Because phytoestrogens are abundant in human and animal food sources, it has been suggested that they can influence hormone-dependent cancers. Besides interacting with ER and PR, phytoestrogens may contribute to low cancer risk by inhibiting aromatase enzymatic activity, decreasing CYP19 gene expression in human tissues (7) and by other biochemical actions identified that lead to tumor suppression and inhibition of neovascularization $(8,9)$. Moreover, phytoestrogens have been applied as an alternative to hormone replacement therapy. In menopausal women, besides improving the cardiovascular system, the lipid and bone metabolism, they also positively affect major symptoms such as hot flushes and mood swings $(10,11)$.

Parsley root (Petroselinum crispum) is a perennial and herbaceous plant. It originated in the Mediterranean region and is cultivated as a dietary and medicinal plant. Parsley root is used in traditional and folklore medicines for digestive disorders, kidney and liver problems, menstrual irregularities 
and for detoxification. It contains a substantial amount of vitamin $\mathrm{C}$ and constitutes as a good source of iron, potassium, calcium, manganese and folic acid $(12,13)$. The active compounds identified in Petroselinum crispum are phenolic compounds, flavonoids (particularly apigenin, apiin and 6acetylapiin) and essential oils - mainly myristicin and apiol (14). Also notable are the photosensitizing furocoumarines bergapten and isoimperatorin in the root that increase the photosensitivity of the skin and are associated with an increased incidence of malignant melanoma (15).

Research on the presence of phytoestrogens in parsley root has attracted little attention. Only the research team led by M. Yoshikawa demonstrated that the methanolic extract from the aerial parts of Petroselinum crispum showed potent estrogenic activity, which was equal to that of isoflavone glycosides from soybean. In addition, they demonstrated that the methanolic extract of parsley, apiin and apigenin restored the uterus weight in ovariectomized mice when orally administered for seven consecutive days (16).

Due to the interesting characteristics of parsley root described above, the current in vitro study aims to identify the molecular chemical composition of parsley root extract (PCE) by mass spectrometry and to evaluate the potential phytoestrogen effects of PCE in terms of DNA synthesis performance (BrdU proliferation assay), metabolic activity (MTT assay) and cytotoxicity (LDH assay) on MCF7 breast cancer and MCF12A benign breast cell lines. Furthermore, the receptor status of MCF7 and MCF12A cells will be determined by immunohistochemical staining of $\mathrm{ER} \alpha, \mathrm{ER} \beta$ and PR.

\section{Materials and Methods}

Origin of the PCE. The parsley root (Petroselinum crispum subsp. tuberosum) was grown, harvested and obtained commercially in 2011 in Mecklenburg-Western Pomerania, at vegetable farming Hofer Neubrandenburg.

Preparation of the PCE. The lignan-isolations were prepared as previously described $(17-18)$. Deep frozen $\left(-20^{\circ} \mathrm{C}\right)$ parsley root $(40 \mathrm{~g})$ was cut into pieces of $5 \mathrm{~mm}$. The pieces were ground in a mortar with liquid nitrogen and extracted under reflux with $360 \mathrm{ml}$ methanol (methanol 99.5\%; Roth, Karlsruhe, Germany) in a water bath at $75^{\circ} \mathrm{C}$. The extract was suspended in $10 \mathrm{ml}$ of distilled water and partitioned with $16 \mathrm{ml}$ ethyl acetate (five times) to give on drying an ethyl acetate soluble residue. After cooling the sample, the larger components were removed twice by using a folded filter (diameter: $185 \mathrm{~mm}$; Schleicher und Schuell GmbH, Dassel, Germany). The solution was then evaporated in a $100 \mathrm{ml}$ round bottom flask using a rotational damper (VV2011, Heidolph Instruments $\mathrm{GmbH} \& \mathrm{Co.KG}$, Schwabach, Germany) under uniform reduction of pressure from 350 mbar to approximately $100 \mathrm{mbar}$. Adhering extract to the wall of the round bottomed flask was removed with $10 \mathrm{ml}$ distilled water and then dissolved in an ultrasonic bath (Ultrasonics (300/H); Omnilab, Bremen, Germany) and extracted 5 times with $16 \mathrm{ml}$ ethyl acetate (99.5\%; Roth,
Karlsruhe, Germany) in a $50 \mathrm{ml}$ Falcon tube. This process leads to significant phase separation into a lower, denser phase (water phase), and an upper phase (lipid phase, containing lignans). The upper phase was carefully aspirated by a pasteur pipette and transferred to a $50 \mathrm{ml}$ round bottomed flask. The sample was again evaporated in a rotational evaporator at $45^{\circ} \mathrm{C}$, under a uniform decrease in pressure from 400 mbar to about 250 mbar. The evaporated extract was dried overnight using a desiccator (with dried silica). To determine the net weight of the extract, the difference of the tare of the round bottom flask and the weight of the flask with dried extract was made (MC1 Analytic scale AC120S; Sartorius $\mathrm{GmbH}$, Göttingen, Germany). The extract was stored protected from light in a refrigerator at $4^{\circ} \mathrm{C}$.

In order to verify the previously reported increased phytoestrogen concentration in PCE the molecular-chemical composition of the extract was further analyzed by pyrolysis-field ionization mass spectrometry by using a LCQ-Advantage (Thermo Finnigan's city $\&$ state). The peaks were identified by ion trap technology on ESI mode. The source voltage was set at $4.5 \mathrm{kV}$ while the mass detection range was 150-2000 amu.

Creation of different PCE concentrations. After determining the weight of the extract it was dissolved with $96 \%$ ethanol (Roth, Karlsruhe, Germany) in an ultrasonic bath (Ultrasonics $(300 / \mathrm{H})$; Omnilab, Bremen, Germany) and the concentration of $100 \mathrm{mg} / \mathrm{ml}$ was determined (stock solution). For the following test series, 7 dilutions (excl. the stock solution) were set at the concentrations of 50,000 $10,000-5,000-1,000-100-10-1 \mu \mathrm{g} / \mathrm{ml}$. The extract was then further diluted, 1:100 giving the final concentrations $500-100-50$ $10-1-0.1$ to $0.01 \mu \mathrm{g} / \mathrm{ml}$. The dilutions were frozen at $-85^{\circ} \mathrm{C}$.

Cell lines. The ER-positive, malignant breast cancer cell line MCF7 and the ER-positive, benign breast cell line MCF12A were used. Both cell lines were obtained commercially from the American Type Culture Collection (ATCC) and for further use in $1.5 \mathrm{ml}$ culture medium (PAA, Germany) $+10 \%$ DMSO $+20 \%$ fetal calf serum (fetal bovine serum, Biochrom, Germany) stored at $-180^{\circ} \mathrm{C}$.

Cell culture. After slow thawing, the cryopreserved cells were washed by $5 \mathrm{ml}$ cell type-specific medium. For MCF7 cells, DMEM, high Glucose 4.5g (PAA, Germany), for MCF12A, Ham's F12 medium (PAA Germany) were used. For this, the cell suspension was carefully pipetted into $15 \mathrm{ml}$ tubes and diluted with $5 \mathrm{ml}$ culture medium. After vortexing and subsequent centrifugation for $5 \mathrm{~min}$ at $1000 \mathrm{rpm}$ (centrifuge Universal 320R Hettich Zentrifugen, Gemany), the supernatant was discarded. The cells were re-suspended in $5 \mathrm{ml}$ culture medium, transferred to $25-\mathrm{cm}^{2}$ cell culture flasks (Biochrom, Germany) and incubated at $37^{\circ} \mathrm{C}, 5 \% \mathrm{CO}_{2}$ for 2-3 days. At a confluence rate of $80 \%$, the medium was changed and the cells were splitted in a larger culture flask $\left(75 \mathrm{~cm}^{2}, 150 \mathrm{~cm}^{2}\right.$, Biochrom, Germany). The cells were rinsed with phosphate buffered saline ( $\mathrm{PbS}$ : Dulbecco's PbS powdered buffer, without Ca \& Mg, PAA, Germany) to remove the upper layer of protein on the cells which would prevent an effective engagement of the trypsin before incubating them with trypsin $\left(10 \%\right.$, trypsin EDTA, PAA, Germany) for $5 \mathrm{~min}$ at $37^{\circ} \mathrm{C}$. The reaction was stopped by adding DMEM (DMEM High Glucose $(4,5 \mathrm{~g}$ ) +L-glutamin; without phenol red, PAA, Germany). The complete detachment of the cells was monitored by light microscopy. Following centrifugation for $5 \mathrm{~min}$ at $1000 \mathrm{rpm}$, the supernatant was discharged and cells were re-suspended in $5 \mathrm{ml}$ cell-specific medium. For MCF7, 
Table I. Salient features of the antibodies used in the present study.

\begin{tabular}{|c|c|c|c|c|}
\hline Antibody/Source & Origin & Dilution in PBS & Incubation & Temperature \\
\hline Anti - ER $\alpha,($ Dako, Germany) & Mouse monoclonal & $1: 150$ & $1 \mathrm{~h}$ & RT \\
\hline Anti - ER $\beta$, (Serotec, Germany) & Mouse monoclonal & $1: 600$ & $\mathrm{O} / \mathrm{N}$ & $4^{\circ} \mathrm{C}$ \\
\hline Anti - PR, (Dako, Germany) & Mouse monoclonal & $1: 50$ & $1 \mathrm{~h}$ & RT \\
\hline
\end{tabular}

O/N: Overnight, RT: room temperature.

$10 \%$ FKS, (PAA, Germany), for MCF12A, 10\% Horseserum, (SIGMA, Germany) were used. Penicillin/Streptomycin $0.2 \%$ (PAA, Germany) and Amphotericin B 0.5\% (PAA, Germany) were added to both cell lines.

Cell counting. Despite the fact that cell proliferation depends on the cell concentration and that cells need contact with neighboring cells in order to grow, when cell count is elevated nutrient shortages occur that may lead to apoptosis. The optimal cell concentration, determined by previous studies was set at $5 \times 10^{5}$ cells $/ \mathrm{ml}$ (19). Most cell vitality assays that allow cell count determination are based on the change in membrane permeability of dead cells. Vital cells are impermeable for dyes such as trypan blue. Therefore, only the colorless cells are counted in phase contrast microscopy. To cell count, $20 \mu \mathrm{l}$ of the cell suspension were diluted with $340 \mu \mathrm{l}$ of cell culture medium and then combined with $20 \mu \mathrm{l}$ trypan blue (corresponding dilution 1:20). To avoid trypan blue staining of intact cells, prompt counting was done. For this, about $20 \mu \mathrm{l}$ of the probe was added to both sides of a Bürker cell counting chamber. Counting was done under a phase contrast microscope at a magnification of $100 x$.

General and statistical considerations. In all tests, a positive control (17 $\beta$-estradiol, E2) and a negative control (tamoxifen, TAM) were carried along with the extract in different concentrations levels. Preliminary tests done using the same workgroup yielded optimal concentrations for E2: $10^{-9} \mathrm{~mol} / 1$ and TAM: $10^{-4} \mathrm{~mol} / 1$. All calculations of the results were performed using Microsoft Excel considering the standard deviation. Statistical analysis was performed using the t-test. Each observation with $p<0.05$ was considered as statistically significant.

Measurement of cytotoxicity by LDH assay. The LDH assay (Roche, Mannheim, Germany) was performed in accordance with the manufacturer's instructions. Best results were achieved after incubation of treated cells $\left(5 \times 10^{5}\right.$ cells $\left./ \mathrm{ml}\right)$ for $24 \mathrm{~h}$ in the absence (controls: TAM, E2) or the presence of PCE at different concentrations. Maximum LDH release (high control) was determined by incubating cells with Triton X-100 at $1 \%$ final concentration (Ferak, Berlin, Germany). Untreated cells were used to determine spontaneous LDH release (low control). After incubation, cells were gently centrifuged for $5 \mathrm{~min} 1,000 \mathrm{rpm}$. Subsequently, cell-free supernatants were carefully removed and transferred into a new 96-well microplate. Supernatants were mixed 1:1 with freshly prepared reaction mixture and incubated protected from light for $30 \mathrm{~min}$ at room temperature. The principle of the assay is based on a $\mathrm{LDH} /$ diaphorase coupled reaction with creation of a red colored formazan. Absorbance of the color was measured at $490 \mathrm{~nm}$ (620 nm wave length was used as a reference).
Proliferation measurement: MTT assay. Cell proliferation was analyzed using an MTT-kit according to the instructions of the manufacturer (Roche, Germany). After incubation of treated cells $\left(5 \times 10^{5}\right.$ cells $\left./ \mathrm{ml}\right)$ for $24 \mathrm{~h}$ in the absence (controls: TAM, E2, N2) or presence of PCE at different concentrations, MTT labelled reagent was added to each well in a final concentration of 0.5 $\mathrm{mg} / \mathrm{ml}$. Subsequently, cells were incubated under culture conditions for $4 \mathrm{~h}$. During this time the metabolic active cells transformed the yellow tetrazolium salt MTT to purple colored formazan crystals. After addition of the solubilization solution the plates were incubated overnight in a humidified atmosphere at $37^{\circ} \mathrm{C}$. With a microplate reader (Model 680, Bio-Rad, Hercules, CA, USA) the color intensity was measured at $570 \mathrm{~nm}$ using a reference wave length of $650 \mathrm{~nm}$.

BrdU proliferation-assay. Cell proliferation was analyzed with a 5bromo-2'-deoxy-uridine (BrdU) labelling and detection kit (Roche, Germany) according to the instructions of the manufacturer. MCF7 and MCF12A cells $\left(5 \times 10^{5}\right.$ cells $\left./ \mathrm{ml}\right)$ were grown in 96 -well tissue culture plates for $24 \mathrm{~h}$ in the absence (controls: TAM, E2, N2) or presence of PCE at different concentrations. After labelling with BrdU for $3 \mathrm{~h}$, the cells were fixed and BrdU incorporation into DNA was measured by an ELISA technique. Cellular proliferation inhibition is expressed in relation to controls $(100 \%) \pm$ SD.

Immunohistochemical staining for the ER $\alpha, E R \beta$ and $P R$. For immuno-detection of the steroid receptors ER $\alpha, E R \beta$ and PR, the Vectastain R Elite ABC-kit (Vector Laboratories, USA) was used according to manufacturer's protocol. The slides were first air dried, rinsed in PBS for 5 min and then incubated with the ABC normal serum for $60 \mathrm{~min}$ in a humidified environment. The slides were then washed again and incubated with the respective primary antibodies. Salient features of the antibodies used are presented in Table I. The slides were then incubated with the diluted biotinylated secondary antibody ( $30 \mathrm{~min})$, followed by incubation with the $\mathrm{ABC}$ reagent (30 min) and the ABC substrate (15 min). A single wash (PBS, 5 min) was applied between steps. Finally, the slides were counterstained with Mayer's acidic hematoxylin (30 sec), rinsed with water and covered with Aquatex.

\section{Results}

Immunohistochemistry. Expression of $\mathrm{ER} \alpha, \mathrm{ER} \beta$ and PR receptors was evaluated in MCF7 and MCF12A cells (Figure 1). A negative control measurement was carried out in which instead of the primary antibody only secondary antibodies were added to show possible non-specific fluorescence signals. In both cell lines secondary antibodies were 

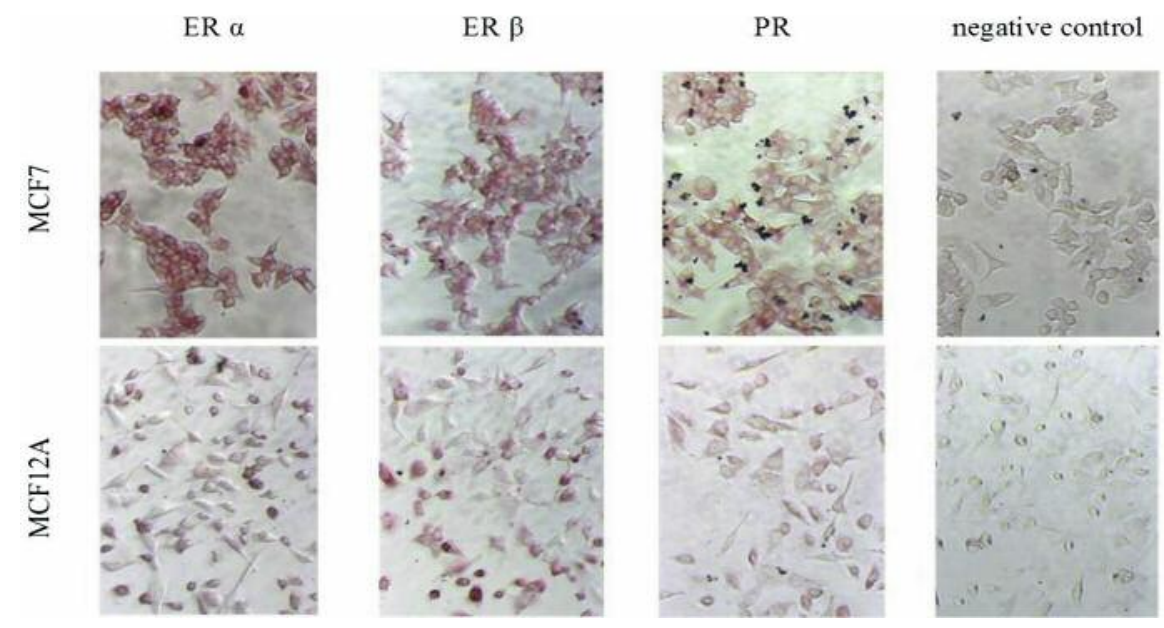

Figure 1. Expression of hormone receptors in cell culture systems (MCF7 \& MCF12A) used for the study.

negative, ruling out non-specific fluorescence signals. ER $\alpha$ demonstrated the strongest expression in both cell lines. ER $\beta$ and PR were less pronounced and comparable in intensity. MCF12A cells expressed lower levels of all receptors tested compared to MCF7 cells, which can be due to the benign nature of MCF12A and its lower metabolic activity and growth rate.

LDH cytotoxicity assay. The lactate dehydrogenase assay (LDH assay) indicates non-specific cytotoxic effects of the given extract that are measurable by enzymatic reactions of LDH. LDH is a cytosolic enzyme that is released from dead cells, making its concentration suitable as a quantitative indicator of cell death. As a positive control and to establish a reference value, cells were incubated with $1 \%$ Triton $\mathrm{X}$ 100 , resulting in complete cell death. LDH activity in these controls was, therefore, set at $100 \%$. Figure 2 shows that no significant cytotoxicity was observed at concentrations of $0.01 \mu \mathrm{g} / \mathrm{ml}$ to $100 \mu \mathrm{g} / \mathrm{ml}$. Also estradiol (E2) did not cause significant cytotoxicity. However, significant cytotoxicity $(p<0.01)$ was caused by PCE at the concentration of 500 $\mu \mathrm{g} / \mathrm{ml}$ in up to $80 \%$ of the cells of both cell lines (MCF7: $74.9 \pm 36.6 \%$, MCF12A: $81.5 \% \pm 14.7 \%$ ), which is approximately equivalent to the effect observed with TAM (MCF7: 69.6\% $\pm 22.6 \%$, MCF12A: $98.7 \% \pm 1.7, p<0.01$ ).

DNA synthesis performance: BrdU proliferation assay. The bromodeoxiuridine (BrdU) proliferation assay provides insights into the DNA synthetic capacity of cells, making it a suitable marker for cell proliferation. During the DNA synthesis phase of the mitotic cycle, cells build the added base analogue BrdU into their genome. An antibody directed against BrdU catalyzes a colour reaction whose intensity directly correlates with the synthetic capacity of the cells. As a reference value, the negative control (N2, ethanol/DMSO) was set at $100 \%$. Figure 3 compares proliferation rates of MCF7 and MCF12A cell lines incubated with the respective extract concentrations. PCE showed less pronounced antiproliferative effects in MCF12A cultures compared to MCF7, as more significant results were obtained using MCF7 cells. At PCE concentrations of $0.01,0.1$ and $1 \mu \mathrm{g} / \mathrm{ml}$, little growth inhibition of MCF12A cells (max. 15\%, at PCE $0.1 \mu \mathrm{g} / \mathrm{ml}: 85.5 \% \pm 5.6 \%, p<0.01)$ was demonstrated. At the concentrations of 50 and $100 \mu \mathrm{g} / \mathrm{ml}$ the antiproliferative effect of PCE in MCF12A intensified, and statistical significance was demonstrated $(50 \mu \mathrm{g} / \mathrm{ml}: 56.7 \% \pm 13.8 \%, p<0.01$, $100 \mu \mathrm{g} / \mathrm{ml}: 61.1 \% \pm 14 \%, p=0.01)$. At $500 \mu \mathrm{g} / \mathrm{ml}$ extract concentration, significant inhibition of proliferation of $84.5 \%$ was noted $(15.5 \% \pm 11.7 \%, p=0.01)$ in MCF12A cells. In MCF7 cells, the PCE concentration of $0.01 \mu \mathrm{g} / \mathrm{ml}$ caused, compared to the concentrations of 1 and $0.1 \mu \mathrm{g} / \mathrm{ml}$ an increased, although not significant inhibition of cell proliferation of approximately $40 \%(61.77 \% \pm 13.0 \%, p=0.08)$. Statistical significant inhibitions over $40 \%$ were demonstrated in MCF7 cells at the concentration levels of 10, 50, 100 and $500 \mu \mathrm{g} / \mathrm{ml}$. The strongest inhibition of proliferation in MFC7 cells of approximately $80 \%$ was observed at a PCE concentration of $100 \mu \mathrm{g} / \mathrm{ml}(19 \% \pm 2.7 \%, p<0.01)$.

Cellular metabolic activity: MTT cell viability assay. Metabolically-active cells have high activity of the mitochondrial enzyme succinate dehydrogenase, whose catalytic activity can be measured directly by a color reaction. High color intensities indicate increased metabolism and cell viability. As a reference value, the negative control N2 was set to $100 \%$. In MFC7 and 


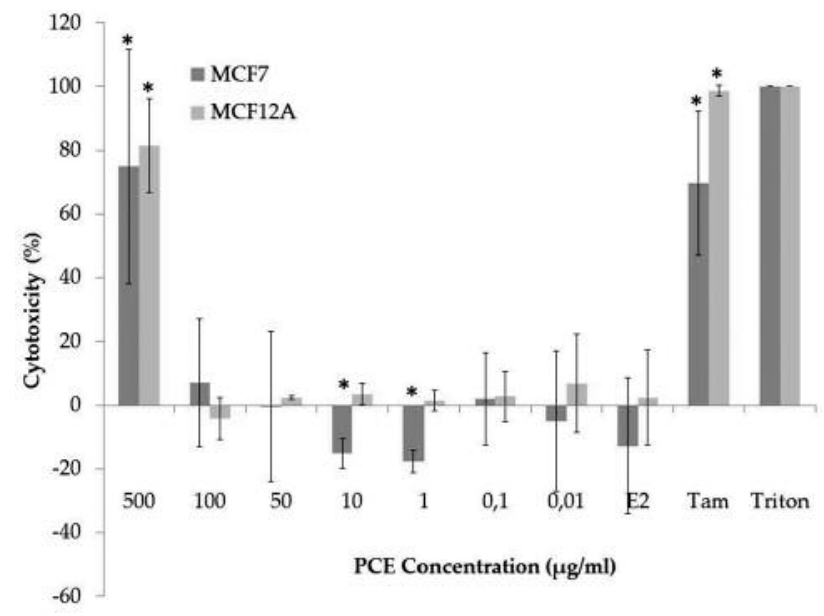

Figure 2. LDH test of the PCE $(\mu \mathrm{g} / \mathrm{ml})$ on MCF7 and MCF12A cells for the assessment of cytotoxicity. Values are given as a percentage of the triton control (100\%). *Marks values below the significance level of $\alpha=5 \%$.

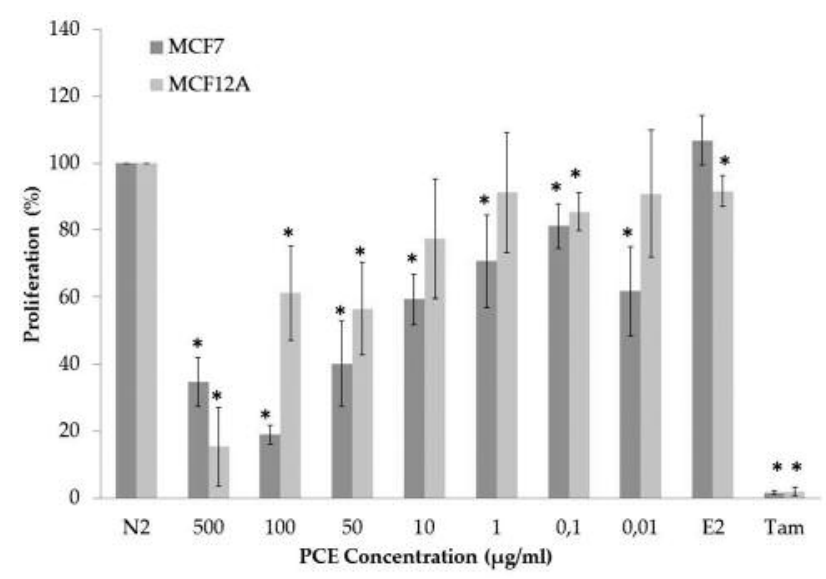

Figure 3. BrdU proliferation test of the PCE in different concentrations $(\mu \mathrm{g} / \mathrm{ml})$ on MCF7 and MCF12A cells for the assessment of cell proliferation. Values are given as a percentage of negative control 2 (N2). *Marks values below the significance level of $\alpha=5 \%$.

MCF12A cell lines, both inhibitory and proliferative effects of PCE were demonstrated. At PCE concentration levels of $0.01 \mu \mathrm{g} / \mathrm{ml}$ to $10 \mu \mathrm{g} / \mathrm{ml}$, weak effects in both cell lines were observed (Figure 4). Generally, metabolic activity was lower in MCF12A cells than in MCF7 cells, except at PCE concentration of $100 \mu \mathrm{g} / \mathrm{ml}$ (MCF12A: $155.7 \% \pm 6.3 \%$, $p<0.01$, MCF7: $144.9 \% \pm 34.5 \%, p<0.01)$. Nevertheless, statistically significant results were found for all MCF12A concentrations, in contrast to MCF7 cells, were increased

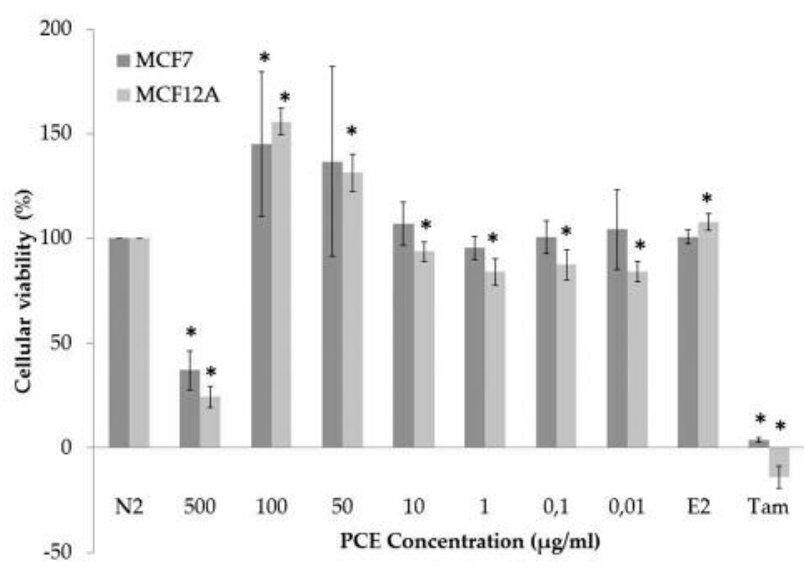

Figure 4. MTT cell viability assay of the PCE at different concentrations $(\mu \mathrm{g} / \mathrm{ml})$ on MCF7 and MCF12A cellscfor the assessment of cellular metabolic activity. Values are given as a percentage of negative control 2 (N2). *Marks values below the significance level of $\alpha=5 \%$.

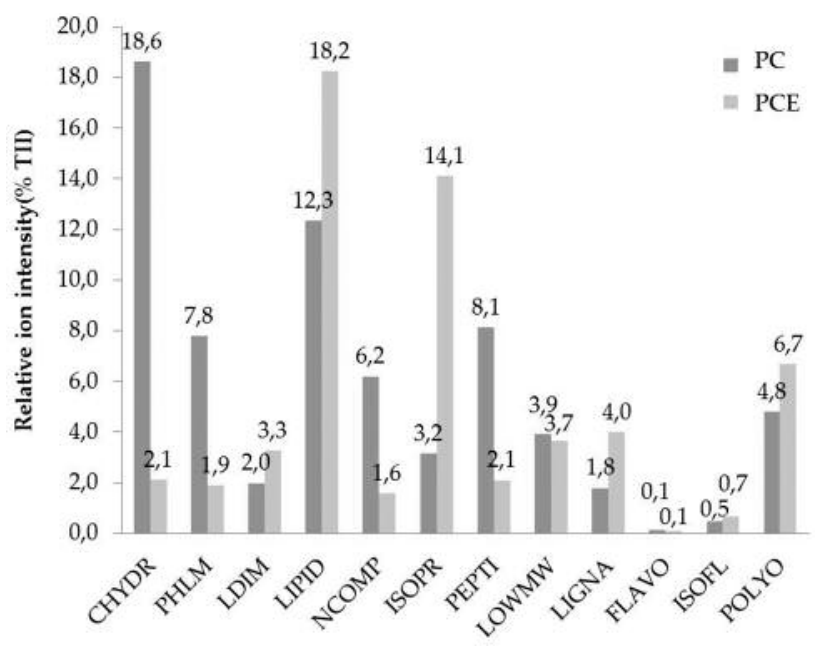

Figure 5. Comparison of the main classes of organic extract components between untreated parsley root $(P W)$ and a parsley root extract $(P W E$, $100 \mathrm{mg} / \mathrm{ml}$, according to Luyengi et al.). The mean values are shown from 3 measurements, expressed as a percentage of the total ion intensity (TI). LIPID=Alkanes, alkenes, aldehydes, alcohols, fatty acids, $n$-alkyl esters, waxes, fats; NCOMP $=N$-containing compounds; $I S O P R=i s o p r e n o i d$ compounds (sterols, terpenes, carotenoids); PEPTI=peptides and free amino acids; LOWMW=low molecular weight compounds $\mathrm{m} / \mathrm{z} 15$ to 56; POLYPH=other polyphenols (suberin, cutin, stilbene, tannins, etc.).

metabolism and significant results were achieved only at concentration levels of $100 \mu \mathrm{g} / \mathrm{ml}$ (proliferative effect, $144.9 \% \pm 34.5 \%, p<0.01$ ) and $500 \mu \mathrm{g} / \mathrm{ml}$ (inhibitory effect, $37.0 \% \pm 9.3 \%, p<0.01)$. Strong, significant inhibition of cell 
growth and metabolic activity was demonstrated in both cell lines at PCE concentration of $500 \mu \mathrm{g} / \mathrm{ml}, 37.0 \% \pm 9.3 \%$ $(p<0.01)$, cell viability for MCF7 cells and $24.4 \% \pm 4 \%(p<0.01)$ for MCF12A cells. No influence on cell viability was observed by E2. However, Tamoxifen caused significant cytotoxicity and thus reduced metabolic activity in both cell lines (MCF7: $3.8 \% \pm 0.9 \%, p<0.01$, MCF12A: $-14.0 \% \pm 5.4 \%, p<0.01)$.

Pyrolysis/FI mass spectrometry. The results from pyrolysis mass spectrometry were compared with masses of different substance classes from public databases. In Figure 5 the main categories identified are presented with the respective percentage of the substance class from the total ion intensity. Untreated parsley root (PC) showed high carbohydrate and lipid fractions (18.6\% and $12.3 \%$ respectively). Peptides and free amino acids are represented with $8.1 \%$, as the third largest group. The extraction process caused a shift of the respective proportions of substances classes, resulting in less carbohydrates $(2.1 \%)$, more lipids $(18.2 \%)$ and more isoprenoids $(14.1 \%)$ in PCE compared to PC. Together, the fractions monolignols, lignin dimers, lignans, flavones, isoflavones and other polyphenols (PHLM, LDIM, LIGNA, FLAVO, ISOFL, POLYO) represent the group of phytoestrogens (PC: 17\%; PCE: 16.6\%).

\section{Discussion}

In this study we demonstrated that PCE has cytotoxic, inhibitory and anti-proliferative effects on cultures of both the benign MCF12A and cancer-derived MCF7 cell lines.

The BrdU proliferation assay was used as the main method to detect inhibitory or stimulatory effects of PCE. To verify its accuracy, a LDH assay was performed to determine cytotoxicity. In both cell lines and at all PCE concentration levels with the notable exception of $500 \mu \mathrm{g} / \mathrm{ml}$, no substantial increase in LDH activity was observed. In combination with the BrdU assay, these results suggest antiproliferative effects of PCE not related to cytotoxicity.

So far, the exact cytotoxic effects of PCE remain unknown. However, according to Dorman et al. it is likely that at high concentrations, toxicity is not mediated by caspase 3 apoptosis pathways but by strong pro-oxidative effects (20). Other possible apoptosis pathways are intrinsic signal molecules (cytochrome $c, \mathrm{p} 53, \mathrm{p} 21$ ) which can be activated by isoflavones, such as genistein $(21,22)$, apigenin (23) and lignans (24).

The BrdU assay showed little to no effect of PCE in both cell lines at low concentrations, but at higher concentrations $(\geq 10 \mu \mathrm{g} / \mathrm{ml}$ ) the following strong inhibitory effects: a reduction of cell proliferation by $42 \%$ in MCF12A (at $50 \mu \mathrm{g} / \mathrm{ml}$ ) and by $80 \%$ in MCF7 cell lines (at $100 \mu \mathrm{g} / \mathrm{ml}$ ). In further studies the effect of PCE at the given different concentrations on $\mathrm{ER} \alpha / \mathrm{ER} \beta / \mathrm{PR}$ expression and the assessment by immunocytochemistry could clarify whether it is likely that MCF12A as a benign cell line is less sensitive to possible antiestrogenic properties of PCE due to a decreased receptor expression compared with malignant MCF7 cells.

A stronger inhibition was demonstrated in MCF12A cells at the concentration of $500 \mu \mathrm{g} / \mathrm{ml}$, attributable to increased cytotoxicity and the associated cell loss. Paradoxically, in MCF7 cells PCE demonstrated a weaker inhibition of cell proliferation at $500 \mu \mathrm{g} / \mathrm{ml}$ than at $100 \mu \mathrm{g} / \mathrm{ml}$, despite cell death rates of up to $75 \%$. Accordingly, the remaining intact cells ( $25 \%)$ would have to operate at a higher synthesis performance than, in this case, $90 \%$ of the cells at a PCE concentration of $100 \mu \mathrm{g} / \mathrm{ml}$. Similar results were obtained by Moorghen et al. (25). They concluded that a higher proliferation rate compensates the cells under apoptosis (secondary effect). However, the low MTT assay values contradict this assumption. At a PCE concentration of $500 \mu \mathrm{g} / \mathrm{ml}$, when high cytotoxicity was reported, low metabolic activity in both cell lines (max. 37\%) was registered.

Interestingly, in MCF12A and MCF7 cells that demonstrated an inhibition of proliferation at the PCE concentrations of $100 \mu \mathrm{g} / \mathrm{ml}$ and $50 \mu \mathrm{g} / \mathrm{ml}$, excessive metabolic activities were reported (max. $155 \%$ in MCF12A cells or max. $145 \%$ in MCF7 cells). A potential explanation is the already mentioned compensatory secondary effect which was also reported by Abarzua et al. in MCF7 cell lines with similar values (26). Moreover, in the E2 control no stimulatory effect on MCF7 cells was observed. Therefore, PCE-induced enhancement of viability at 100 and $50 \mu \mathrm{g} / \mathrm{ml}$ is probably not related to an ER-mediated process. Other possibilities that increase cellular viability at 100 and $50 \mu \mathrm{g} / \mathrm{ml}$ could be the activation of protective or resistance pathways (elimination of the active compounds by MDR transporters, metabolic detoxification, activation of alternative metabolic pathways). At low PCE concentrations $(10 \mu \mathrm{g} / \mathrm{ml}-0.01 \mu \mathrm{g} / \mathrm{ml})$ no eminent metabolic changes were visible, matching the weakly altered proliferation status of the MCF7 and MCF12A cells.

Only one other study investigating the phytoestrogen effects of Petroselinum crispum on MCF7 cell lines exists (16) where the influence of parsley leaf extracts and other isolates on MCF7 breast cancer cell lines was investigated. The methanol extract showed progesterone-like properties associated with increased proliferation rates of up to $156 \%$ (at a concentration of $10 \mu \mathrm{g} / \mathrm{ml}$ ). However, the cell proliferation was not measured by BrdU but only with the MTT assay. It reported similar MTT values $(155 \%$ at a concentration of $100 \mu \mathrm{g} / \mathrm{ml}$ in MCF12A cell cultures). However, it remains unclear to what extent the cellular metabolic activity is linked with the proliferation rate.

In all assays, estrogen was used as a positive control. In both cell lines it demonstrated no significant cytotoxicity and proliferation compared with the negative control. Previous works using the same cell lines demonstrated similar results 
$(27,28)$. It is likely that both receptor subtypes $(E R \alpha / E R \beta)$ are activated by E2, whereby ER $\beta$ intracellularly suppresses the proliferative effect of ER $\alpha$. Thus the ratio of the expression of $E R \alpha / E R \beta$ would be decisive for the different proliferation patterns of the cells. Immunohistochemistry analysis showed that both ER $\alpha$ and ER $\beta$ are present on cells (Figure 1). Looking at the images, it is evident that the ER $\beta$ expression is weaker but likely strong enough to inhibit ER $\alpha$ mediated cell proliferation.

TAM, which was used as a negative control is a SERM used for the treatment of hormone-sensitive breast cancer for already more than twenty years. It acts as a competitive inhibitor or partial agonist on the ER. On breast cancer cell lines it has an inhibitory effect (29). Correspondingly, a high cytotoxicity and a low metabolism and proliferation were observed in both cell lines treated with TAM.

Previous results demonstrated that PCE has anticarcinogenic properties. The question of whether and to what extent phytoestrogens are involved cannot be answered precisely. For this reason, mass spectrometry was performed which provided information on the different extract components. In order to determine the efficiency of the extraction method used based on the Luyengi et al. study, a sample of $5 \mathrm{mg}$ raw material (PC) was analyzed in addition to the extract sample.

Mass spectrometry of PCE and PC demonstrated a loss of carbohydrates, monolignols, and nitrogen-containing compounds as well as free amino acids in PCE compared to PC. Except for the monolignols these compounds are not probable constitutes of phytoestrogens. An increase in concentration was registered in the groups of lipids, isoprenoids, lignindimeres, lignans and other polyphenols. Particularly the latter three groups are known to have phytoestrogen activity. This leads to a total sum of $16.6 \%$ phytoestrogen compounds in the PCE. The isoprenoids group contains sterols such as cholesterol (animal) and ergosterol (fungi/protozoa). Other metabolites can form steroids or steroid hormones like estradiol. It seems likely that isoprenoids may have estrogenic activity. Further, nonestrogenic effects can be found in the group of lipids: free fatty acids inhibit cell proliferation through activation of peroxisome proliferator-activated receptors PPAR $\alpha$ and $\operatorname{PPAR} \gamma$, which bind as transcription factors to the promoters of retinoid $\mathrm{X}$ receptors, regulating the expression of various genes $(30,31)$. In MCF7 breast cancer cells, PPAR $\gamma$ counteracts the transcription factor $\mathrm{NFKB}$, inducing the promoter of $p 53$ to drive apoptosis (32). Also, the group the alkyl esters cytotoxic effects have been assigned: $n$-alkyl ester as a basic component of the (methyl) acrylates have lipophilic side groups that mediate cytotoxicity (33). Due to the overall high percentage of lipids $(18.2 \%)$ in PCE it cannot be ruled out that phytoestrogens exhibit little or no influence on its overall effect. Therefore, in further studies, lipopolysaccharide could be used as an additional control substance to demonstrate the extent to which lipids are involved in the observed effects.

So far, few studies have been conducted with extracts of Petroselinum crispum. Differently to our study, Yoshikawa et al. used a methanol extract of the leaves, but not of the root (16). By means of high pressure liquid chromatography various fractions were separated and subsequently detected by electron impact mass spectrometry. Ten individual substances were identified, of which five possess proven anti-estrogenic properties: apigetrin, apiin, diosmetin, kaempferol, 6-acetylapiin (all from the group of flavone glycosides, which also include the strong growth inhibitors genistin and daidzein). Furthermore, an increase in uterine weight of ovariectomized mice fed with the parsley leave extract was observed, which suggests progesterone like growth-promoting effect.

This work proved that PCE causes anti-carcinogenic effects on MCF7/MCF12A cell lines. Growth inhibitory potency of parsley root extract (PCE) on MCF7 mammary tumor cells at non-toxic concentrations (up to $100 \mu \mathrm{g} / \mathrm{ml}$ ) was reported. Complementary observation of a less marked inhibition on related MCF12A benign cells suggests an ER-mediated process. Whether this apparent anti-carcinogenic effect of PCE can be solely attributed to its phytoestrogens requires complementary investigations. As a possible approach to determining the role of hormone receptor mediated cell response, PCE could be tested on malignant and benign ERnegative cells (e.g. BT-20/MCF-10A). Additional control substances to assess the lipid signal pathway, such as lipopolysaccharide could demonstrate the extent to which lipids are involved in the effects observed. Furthermore, fractional chromatography could provide information of the individual substances and their impact on breast cancer cell lines. Cytotoxicity could be evaluated in detail by immunohistochemistry or RTQ-PCR quantification apoptosis induced markers like, p53,p21, BCL2 and Caspase 8/9. Other extraction methods besides the ones used (17) could probably create qualitatively improved extracts (e.g., water extraction, resuspension of the dry extract in various solvents).

\section{References}

1 Siegel R, Ma J, Zou Z and Jemal A: Cancer statistics, 2014. CA Cancer J Clin 64: 9-29, 2014.

2 Burstein HJ, Temin S, Anderson H, Buchholz TA, Davidson NE, Gelmon KE, Giordano SH, Hudis CA, Rowden D, Solky AJ, Stearns V, Winer EP and Griggs JJ: Adjuvant Endocrine Therapy for Women With Hormone Receptor-Positive Breast Cancer: American Society of Clinical Oncology Clinical Practice Guideline Focused Update. J Clin Oncol 32: 2255-2269, 2014.

3 Effects of chemotherapy and hormonal therapy for early breast cancer on recurrence and 15-year survival: an overview of the randomised trials. Lancet 365: 1687-1717, 2005. 
4 Tham DM, Gardner CD and Haskell WL: Clinical review 97: Potential health benefits of dietary phytoestrogens: a review of the clinical, epidemiological, and mechanistic evidence. J Clin Endocrinol Metab 83: 2223-2235, 1998.

5 Usui T: Pharmaceutical prospects of phytoestrogens. Endocr J 53: 7-20, 2006.

6 Setchell KD: Phytoestrogens: the biochemistry, physiology, and implications for human health of soy isoflavones. Am J Clin Nutr 68: 1333S-1346S, 1998.

7 Lephart ED: Modulation of Aromatase by Phytoestrogens. Enzyme Res 2015: 594656, 2015.

8 Ahmad A, Biersack B, Li Y, Kong D, Bao B, Schobert R, Padhye SB and Sarkar FH: Deregulation of PI3K/Akt/mTOR signaling pathways by isoflavones and its implication in cancer treatment. Anticancer Agents Med Chem 13: 1014-1024, 2013.

9 Fotsis T, Pepper M, Adlercreutz H, Hase T, Montesano R and Schweigerer L: Genistein, a dietary ingested isoflavonoid, inhibits cell proliferation and in vitro angiogenesis. J Nutr 125 : 790S-797S, 1995.

10 Dodin S, Blanchet C and Marc I: Phytoestrogens in menopausal women: a review of recent findings. Médecine Sci M/S 19: 1030-1037, 2003.

11 Moreira AC, Silva AM, Santos MS and Sardão VA: Phytoestrogens as alternative hormone replacement therapy in menopause: What is real, what is unknown. J Steroid Biochem Mol Biol 143: 61-71, 2014.

12 Mahmood S, Hussain S and Malik F: Critique of medicinal conspicuousness of Parsley (Petroselinum crispum): a culinary herb of Mediterranean region. Pak J Pharm Sci 27: 193-202, 2014.

13 Pápay ZE, Kósa A, Boldizsár I, Ruszkai A, Balogh E, Klebovich I and Antal I: Pharmaceutical and formulation aspects of Petroselinum crispum extract. Acta Pharm Hung 82: 3-14, 2012.

14 Farzaei MH, Abbasabadi Z, Ardekani MRS, Rahimi R and Farzaei F: Parsley: a review of ethnopharmacology, phytochemistry and biological activities. J Tradit Chin Med 33: 815-826, 2013.

15 Dowdy JC and Sayre RM: Melanoma Risk From Dietary Furocoumarins: How Much More Evidence Is Required? J Clin Oncol 34: 636-637, 2016.

16 Yoshikawa M, Uemura T, Shimoda H, Kishi A, Kawahara Y and Matsuda H: Medicinal foodstuffs. XVIII. Phytoestrogens from the aerial part of Petroselinum crispum MIll. (Parsley) and structures of 6"-acetylapiin and a new monoterpene glycoside, petroside. Chem Pharm Bull (Tokyo) 48: 1039-1044, 2000.

17 Luyengi L, Suh N, Fong HH, Pezzuto JM and Kinghorn AD: A lignan and four terpenoids from Brucea javanica that induce differentiation with cultured HL-60 promyelocytic leukemia cells. Phytochemistry 43: 409-412, 1996.

18 A M: Untersuchungen zur Wirkung von Pflanzenextrakten aus Linum usitatissimum, Secale cereale und Pisum sativum auf die Zellproliferation und Progesteronproduktion von humanen Trophoblasttumorzellen. Diplomarbeit, Univ Rostock, Fachbereich Biowissenschaften, Abteilung Biochem, 2003.

19 Abarzua S, Serikawa T, Szewczyk M, Richter D-U, Piechulla B and Briese V: Antiproliferative activity of lignans against the breast carcinoma cell lines MCF 7 and BT 20. Arch Gynecol Obstet 285: 1145-1151, 2012.

20 Dorman HJD, Lantto TA, Raasmaja A and Hiltunen R: Antioxidant, pro-oxidant and cytotoxic properties of parsley. Food Funct 2: 328-337, 2011.
21 Jin C-Y, Park C, Kim G-Y, Lee S-J, Kim W-J and Choi YH: Genistein enhances TRAIL-induced apoptosis through inhibition of p38 MAPK signaling in human hepatocellular carcinoma Hep3B cells. Chem Biol Interact 180: 143-150, 2009.

22 Ullah MF, Ahmad A, Zubair H, Khan HY, Wang Z, Sarkar FH and Hadi SM: Soy isoflavone genistein induces cell death in breast cancer cells through mobilization of endogenous copper ions and generation of reactive oxygen species. Mol Nutr Food Res 55: 553-559, 2011.

23 Seo H-S, Choi H-S, Kim S-R, Choi YK, Woo S-M, Shin I, Woo J-K, Park S-Y, Shin YC, Ko S-G and Ko S-K: Apigenin induces apoptosis via extrinsic pathway, inducing p53 and inhibiting STAT3 and NFKB signaling in HER2-overexpressing breast cancer cells. Mol Cell Biochem 366: 319-334, 2012.

24 Stattin P, Adlercreutz H, Tenkanen L, Jellum E, Lumme S, Hallmans G, Harvei S, Teppo L, Stumpf K, Luostarinen T, Lehtinen M, Dillner J and Hakama M: Circulating enterolactone and prostate cancer risk: a Nordic nested case-control study. Int J cancer 99: 124-129, 2002.

25 Moorghen M, Orde M, Finney KJ, Appleton DR and Watson AJ: Sulindac enhances cell proliferation in DMH-treated mouse colonic mucosa. Cell Prolif 31: 59-70, 1998.

26 Abarzua S, Serikawa T, Szewczyk M, Richter D-U, Piechulla B and Briese V: Antiproliferative activity of lignans against the breast carcinoma cell lines MCF 7 and BT 20. Arch Gynecol Obstet 285: 1145-1151, 2012.

27 Richter D, Abarzua S, Chrobak M, Vrekoussis T, Weissenbacher T, Kuhn C, Schulze S, Kupka MS, Friese K, Briese V, Piechulla B, Makrigiannakis A, Jeschke U and Dian D: Effects of phytoestrogen extracts isolated from pumpkin seeds on estradiol production and ER/PR expression in breast cancer and trophoblast tumor cells. Nutr Cancer 65: 739-745, 2013.

28 Theil C, Briese V, Richter D-U, Jeschke U and Friese K: An ethanolic extract of Linum usitatissimum caused cell lethality and inhibition of cell vitality/ - proliferation of MCF-7 and BT20 mamma carcinoma cells in vitro. Arch Gynecol Obstet 288: 149153, 2013.

29 Lochab S, Pal P, Kanaujiya JK, Tripathi SB, Kapoor I, Bhatt MLB, Sanyal S, Behre G and Trivedi AK: Proteomic identification of E6AP as a molecular target of tamoxifen in MCF7 cells. Proteomics 12: 1363-1377, 2012.

30 Dionisi M, Alexander SPH and Bennett AJ: Oleamide activates peroxisome proliferator-activated receptor gamma (PPAR $\gamma)$ in vitro. Lipids Health Dis 11: 51, 2012.

31 Thoennes SR, Tate PL, Price TM and Kilgore MW: Differential transcriptional activation of peroxisome proliferator-activated receptor gamma by omega- 3 and omega- 6 fatty acids in MCF-7 cells. Mol Cell Endocrinol 160: 67-73, 2000.

32 Bonofiglio D, Aquila S, Catalano S, Gabriele S, Belmonte M, Middea E, Qi H, Morelli C, Gentile M, Maggiolini M and Andò $\mathrm{S}$ : Peroxisome proliferator-activated receptor-gamma activates p53 gene promoter binding to the nuclear factor-kappaB sequence in human MCF7 breast cancer cells. Mol Endocrinol 20: 3083-3092, 2006.

33 Yoshii E: Cytotoxic effects of acrylates and methacrylates: relationships of monomer structures and cytotoxicity. J Biomed Mater Res 37: 517-524, 1997.

Received September 26, 2016

Revised November 2, 2016

Accepted November 14, 2016 